\title{
Accounting Students and Business Ethics Perception
}

\author{
Sheila Febriani Putri ${ }^{1 *}$, Dwi Hantoro Prakoso ${ }^{2,}$ Septy Nur \\ Sulistyawati $^{3,}$ Siti Mariyah ${ }^{4}$
}

\author{
1, 2, 3, 4 State University of Malang \\ *Corresponding author. Email: Sheila.febriani.fe@um.ac.id
}

\begin{abstract}
Ethical violence which is often commited by businesspersons in Indonesia and the high interest of students to become an enterprenure make business ethics even more important to being studied. Business ethics subject is an effort to increase the students' understanding about business ethics components. So far, research about ethics is dominated by profession ethics. Therefore, it is important conducting a research about business ethics. The educational institution needs to involve the students in making the policy about business ethics curriculum. Therefore, the research focusing on the students' perception needs to be done.
\end{abstract}

This research applied qualitative methods with phenomenology approach. The source of the data used in this research was primary data from the questionnaires. Research subject consisted of 53 accounting students of Malang University. The step of data analysis consists of data reduction, data presentation and conclusion.

The result of this research showed that the students perceive ethics as a rule for people about the good and bad things, right or wrong, which is used as life guidance, while business ethics is a rule for the businesspersons (company, individual in the company) in doing their business. Ethics is related to religion and value in rationality searching. The difference of law, ethics and etiquette are on their scope. Ethics is not limited on the way how an action is done, while etiquette is only valid on the association. Meanwhile, the scope of the law is much wider and has force element. In understanding ethics, there is an intact human paradigm which means as a form of human balance in living their life. The whole respondent agreed that learning business ethics is important for accounting business as well as accounting education.

Keywords: Business Ethics, Students' Perception, Behavior

\section{INTRODUCTION}

A business ethics scandals in Indonesia are becoming more frequent, from the General Company of Indonesian Fishing with bribery case amount of US\$30.000, PT Garuda Indonesia in aeroplanes procurement, and Pertamina Energy Services (PES) Private Limited related to trading activity (Salama, 2020). Ethical violence is not only commited by large-scale companies, but also by sectors, such as property sector, sugar distribution, medical devices and product composition (Gulo, 2019). This indicates that there is a supervision conducted by the stakeholders in doing the business and it gives a great impact for internal and external parties (Royaee, 2013). This is triggered by the difference of interests and selfishness feeling in taking decision. Therefore, stakeholders need guidance in every situation in order to take an action with moral awareness (Hasoloan, 2018).

The comprehension of ethics concept has an important role in managing a company and being foundation to establish profitable business condition so being oriented to the whole parties (Muslim, 2019). Business ethic is crucially important in providing a chance for education to contribute in giving a better comprehension for agent of change (Stăiculescu, 2015). Education is also having a role to fill the needs of ethics (Cohen, 2001). Business ethics subject is a form of moral awareness. However, the problem is still found when talking about business ethics, such as confusion, worry, and misunderstanding about ethics and 
dissatisfaction with ethics education from the given content point of view (Marques, 2019). Moreover, Sigurjonsson, et. al (2015) stated that all students need to understand the importance of business ethics. However, there are many business graduates who do not understand business ethics well. This research observed from a different point of view by involving accounting students as the research subject.

Nowadays, economic development with a competitive market is higher, relying on theory to get the best graduate is not enough. Thus, learning through practiceoriented is really required to see the ability level of learners (Marques, 2019). In addition

\section{LITERATURE REVIEW}

The discussion related to business ethics become the attention of academic people as well as practitioners. Business ethics violence that frequently happened in Perindo, Garuda and Pertamina makes people worry about unethical action. In the other hand, there is also growing interest in entrepreneurship among young generation. Therefore, academic people need to scrutinize the requirement and improve ethic scope in accounting curriculum. According to Adkins, an ethical lesson in accounting education has seven target, namely (1) to relate accounting education with the moral problem, (2) to discuss accounting problems that implied ethics, (3) to develop obligation and responsibility, (4) to develop the ability to face conflict and ethical dilemma, (5) to learn how to face uncertainty in accounting profession, (6) to learn the change of ethical behavior, and (7) to collaborate the aspect of accounting ethics towards general ethics. Based on that, the study about ethics and ethical education is important to be done as an effort to increase the role of accounting profession in current condition (Budiarto, 2011).

Ethics is a value which can be stated whether something is good or bad, right or wrong (Amberla, 1988). In line with that, Freeman et, al (1988) and Carroll (1991) define ethics as a concept about what right and fair behavior. Ethics is not only for individual, but also for businesspersons as well as for organisation. According to De George, interaction between ethics and business can be defined as a concept of business ethics related to the moral standard to business ethics violence, the increase of the students' interest in business becomes the stimulus for the students' need and understanding towards ethics (Kemenristekdikti, 2019; Satrya, 2015). Through business ethics, people can get the better insight to understand the challenge faced in a holistic manner to solve the problems (Holland, 2013). Based on the problem explained before, this research is important being conducted. The purpose of this research is to reveal the accounting students' understanding towards business ethics.

and principal things in operating the business (Ferrel, 1997). Thus, it can be said that business ethic is a part of ethics containing value or actions which can be done or not in operating the business.

The awareness about practical ethics by modern society grows substantially (Ahmed, et.al, 2003). As the consequence, the ethical aspect becomes crucially important and gives direct impact to the company and businesspersons (Amberla, et.al, 1988). University, as the institution that prepares business figures, has a role in embedding ethics to the students. In making the decision related to business ethics subject, it is important to involve the students for evaluation. One thing that needs to be known by education institutions is students' perception related to the business ethics comprehenison.

Perception is the combination from stimulus visual (an outside world) and the previous knowledge of (Agustina, 2017). Meanwhile, Robbins (2001) stated that perception is an individual process in organizing and defining the impression by their sense so they can be meaningful for the environment. Based on that, it can be concluded that perception is the result of a combination the previous knowledge and the fact that is captured by human sense towards something. People perception can be affected by experience, learning process, insight and knowledge (pararuk, 2018).

\section{RESEARCH METHOD}

This research is qualitative research with phenomenology approach. Qualitative methods chosen because it is an appropriate with the research purpose, to find the 
meaning of a phenomenon happening in social life (Meleong, 2012). This research analysed the events, a phenomenon, attitude, and students' perception related to business ethics. The data source in this research is primary data from direct interview with the research subject of 53 accounting students of State University of Malang.

This research applied thematic analysis techniques by classifying the data from the interview into the theme or the category from the information inductively (from the interview) as well as deductively (from the previous research) (Boyatzis, 1998). The step of data analysis applied refers to theory proposed by Miles \& Huberman (1992).

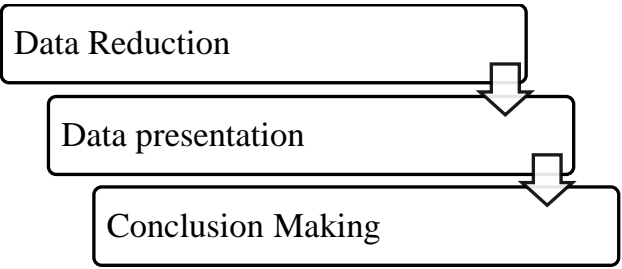

Figure 1. The Step of Data Analysis

The step of data reduction conducted in this research was by collecting, overviewing, and categorizing the data in a certain concept or theme. The data collected from this research was classified based 6 subquestion in the interview, they are (1) the definition of ethics; (2) the relation among law, ethics, and value; (3) the difference of law, ethics, and etiquette; (4) human paradigm entirely; (5) the understanding of business ethics; and (6) the importance of business ethics for accounting and educational accounting students. Then, the data presented by combining the whole information in detail and integrated form in order to create keywords in research. After the data was presented in a comprehensive form, the researcher made a conclusion to answer the research problem.

Triangulation technique used in this research to check on the data validity. Meleong (2012) stated that triangulation is a technique to check on the data validity by using the instruments outside the data as a comparison or a benchmark towards the data collected. This research applied source triangulation conducted by giving the same questions for the different informant in order to measure the credibility of the given information.

\section{RESULTS AND DISCUSSION}

\subsection{The Definition of Business and Business Ethics}

Etymologically, ethics derived from Greek, namely ethos and ethikos. Ethos is the habit related to character, personality and place, ethikos is politeness, courtesy, actions and good behavior (Loren, 2000). Ethics is also defined as the obligation and prohibition that need to be obeyed (Keraf, 2002). According to the result of the interview, it can be concluded that the students perceive ethics as a rule for the people about good and bad, right or wrong as guidance in living their life. Some respondents also said that ethics is a critical and rational reflection about the norm which determines people's attitude as well as behavior. The following are the statements from respondents "Ethics is a norm or rule as the guidance for behaving in the society for someone related to good or bad character".

Ethics in the meaning of a rule is also interpreted as an unwritten rule. As said by one of the respondents "ethics is an unwritten rule which is done in society or in a social life, it indicates that ethics related to selfawareness. Ethics also can not be separated from the environment, so ethics is important for the individual to survive in the society, as one of respondents said "Ethics is a rule or norm as guidance in a society about something good and right or bad and wrong". It interprets that it is important to obey ethics in social life.

Besides for an individual, obeying the ethics is also important for the businessman or the company because the company is a part of the society. Because of that, business ethics is known as the value or rules in doing economic activities (Ahmed, 2003). Based on the interview, respondents perceive business ethics as a rule for business (company, individual in the company) in doing their business. Business ethics is important as an effort to prevent any action that will harm the environment or the society as it was said by one of the respondents as follow "Business ethics is the procedures of business management that concern on the norm and morality without harming any parties or individual". 
Based on the interview, it can be concluded that business ethics is a part of ethics. Ethics explain about norm or rules for the individual in social life, whereas business ethics explains the rules for the business (company) in managing their operation or business. Ethics and business ethics are related to behavior. Therefore, ethics is important for human life to decrease the disadvantage caused by immoral action.

\subsection{The Relation of Religion, Ethics, and Value}

Religion becomes the highest level as the guidance for the people in living their life. The orientation of basic life is also based on religion (Kristanto,2014). According to Nizar (2018), religion is a base in doing an action according to the rules appointed by God. In religion, ethics skill is needed to give orientation, not only indoctrination (Suseno, 1996). Basically, people who has belief will expect a rational religion dogma by believing in God. Ethics play a role to help people to search on rationality of religion morality as well as the value containing religious advice about moral.

Perceiving the feedback given by the respondents, basically, there is a strong relationship among religion, ethics, and value (See Figure 2). Religion requires someone to behave according to ethics and if someone has good ethics, it means that everything they done is based on the moral value. Those three things can not be separated, moreover, religion will always teach moral value and create the balance in life.

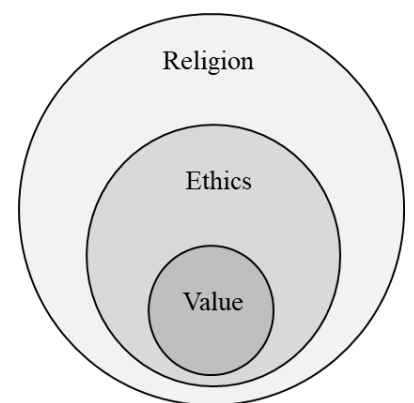

Figure 2. The Relation among Religion, Ethics and Value

\subsection{The Difference of Law, Ethics and Etiquette}

Law, ethics and etiquette in human life contains about the principals that regulate evey action. Kristanto (2014) stated that there is the difference among law, ethics and etiquette. Law is the rules that force and punish people if they do not comply, whereas ethics has a higher standard than law. Moreover, ethics is not only related to behavior, but also related to motivation and character. Meanwhile etiquette is generally defined the same as ethics, but etiquette is more focus on politeness and control on what must be done.

Based on the interview result, it can be concluded that law is a rule instrument set directly by the state institution, whereas ethics grows naturally in society. Moreover, law has enforcement to be obeyed, while ethics is done according to conscience and awareness to obey it. The difference that was told by the interviewees related to ethics and etiquette lies on the scope of the given rules, ethics is not only restricted on the way how an action is done, whereas etiquette is restricted on association. The following are respondent statements:

"Ethics and etiquette control human behavior normatively, means that it gives norm for human and state what must be done and what not allowed to be done, while law control obligation and enforcement".

The difference basically has the same purpose, to control or give reference to the society to live their life according to the prevailing norms legally as well as in society.

\subsection{Human Paradigm Entirely}

Human paradigm entirely is related to balance, consisting of right and obligation, worldly and spiritual purpose, individual interest and society interest as well as defining the meaning of life as a process of awareness evolutionary (Wirawan, 2012). Several response given by the respondents related to human paradigm entirely indicates their point of view as follow; (1) defining completely human as the balance of competence and ethics, (2) completely human as the comprehension of human essential (3) the character consiting of mind, physical and body and soul, (4) point of view which will influence the attitude and behavior, and (5) there are 4 dimensions inside human: body, intelligence, heart, and soul. However, there are some respondents that do not understand yet the entirely of human paradigm. The statements are as follow:

\section{"Not understand."}

"I don't really understand about the entirely of human paradigm." 


\subsection{The Importance of Business Ethics for Accounting Students}

Studying and applying business ethics is important by the businesspersons. According to Siagian (1996), there are at least 4 reasons why it is so important to study: (1) ethics gives guidance for an individual in taking the decision in life, (2) ethics give images about the behavior for the more harmonious life, (3) a dynamic life makes the change in moral value, so analysis and overview about ethics need to be done, (4) ethics encourage individual to have good character and behave according to the moral value. Based on the interview, all participants stated that accounting and educational accounting graduates need to have comprehension about business ethics.

The result showed 4 reasons why studying business ethics is so important for educational accounting students, (1) business ethics teach moral norm and moral value that can be applied in any institutions, technologies, transactions, activities, and business, (2) Making it easier for someone easier to take a decision according to norm and morality universally, economically, as well as socially, (3) studying business ethics can avoid us from any bad action, such as fraud, (4) as an accountant or accounting instructor candidate, accounting and educational accounting graduates are required not only to have ability and knowledge, but also principal and ethics commitment in business whether for being applied for himself as well as to be taught for others (accounting instructor).

\section{CONCLUSIONS}

Based on the result of the interview, it can be concluded that students embrace the ethic as a guidance in distinguishing between bad or goor, wrong or right in making decision. Meanwhile, business ethics in students' perception is a rule for businesspersons (company, individual in the company) in managing their business. Ethics also has strong relation with religion and value in searching for rationality of morality. Ethics is different from law and etiquette in its scope. Ethics is not only restricted on the way how an action is done, whereas etiquette is restricted on association, and law has a wider scope and the power of enforcement.
In understanding ethics, there is a completely human paradigm which means as a form of human balance in living their life. All respondents agreed that learning business ethics is important for accounting as well as educational accounting students. Business ethics is important for the students because it teach norm and moral value that can be applied in daily life. Business ethics give consideration to make it easier to take decision in dilemmatic condition. Studying business ethics can avoid us from bad deeds and as an accountant or accounting instructor candidates, accounting and educational accounting graduates are required not only to have ability and knowledge, but also to have a principal and ethics commitment.

The limitation in this research is that the research subject is only limited to students at one of the universities in Malang city. Thus, the next research is expected to have a wider research subject from the various educational institution or even across generations.

\section{REFERENCES}

[1]. Ahmed, M. M., Chung, K. Y., \& Eichenseher, J. W. (2003). Business students' perception of ethics and moral judgment: A cross-cultural study. Journal of Bussiness Ethics, 43, 89-102. doi: 10.1023/A:1022915316112.

[2]. Adkins, N., \& Radtke, R. R. (2004). Students' and faculty members' perceptions of the importance of business ethics and accounting ethics education: Is there an expectations gap? Journal of Business Ethics, 51(3), 279-300. doi: 10.1023/b:busi.0000032700.07607. 02.

[3]. Agustina, R., Suarniki, N. N., \& Suyanti. (2017). Persepsi mahasiswa akuntansi berdasarkan gender terhadap etika bisnis dan etika profesi (Studi Kasus: PTS dan PTN di Kota Banjarmasin. Jurnal Ekonomi dan Bisnis, 10(1), 142155 .

[4]. Amberla, T., Wang, L., Juslin, H., Panwar, R., Hansen, E., \& Anderson, R. (1988). Students' perceptions of forest industries business ethics: A comparative analysis of finland and the USA. 
New Jersey: Prentice Hall. Retrieved from http://ejbo.jyu.fi/pdf/ejbo_vol 15 no1_pages_44-54.pdf.

[5]. Budiarto, D. S. (2011). Analisis perbedaan persepsi antara mahasiswa dengan pendidik terhadap etika bisnis. Akmennika UPY, 7, 26-37.

[6]. Boyatzis, R. E. (1998). Transforming qualitative information: Thematic analysis and code development. London: Sage Publication.

[7]. Caroll, A. B. (1991). The pyramid of corporate social responsibility: toward the moral management of organizational stakeholders. Bussiness Horizon, 29(4), 22-27.

[8]. Cohen, J. R., Pant, L. W., \& Sharp, D. J. (2001). An examination of differences in ethical decisionmaking between Canadian business students and accounting professionals. Journal of Business Ethics, 30(4), 319-336. doi: 10.1023/A:1010745425675.

[9]. Ferrell, O. C., \& Fraedrich, J. (1997). Business ethics: Ethical decision making and cases [ $\left.3^{\text {rd }} e d\right]$. Boston: Houghton Mifflin.

[10]. Freeman, R. E., \& Gilbert, D. R. (1988). Corporate strategy and the search for ethics. New Jersey: Prentice Hall.

[11]. Gulo, Y. (July, 2019). Maraknya pelanggaran etika bisnis, merusak dunia usaha dan industri. Retrieved from

https://www.kompasiana.com/yupite r/5d3e6931097f363fa7635a22/mara knya-pelanggaran-etika-bisnismerusak-dunia-usaha-dan-industri.

[12]. Hasoloan, A. (2018). Peranan etika bisnis dalam perusahaan bisnis. Journal Warta Darmawangsa, 57,121-130. Retrieved from http://ec.europa.eu/energy/res/legisla tion/doc/biofuels/2006_05_05_cons ultation_en.pdf\%0Ahttp://dx.doi.org /10.1016/j.saa.2017.10.076\%0Ahttps ://doi.org/10.1016/j.biortech.2018.07 $.087 \%$ Ahttps://doi.org/10.1016/j.fu el.2017.11.042\%0Ahttps://doi.org/1 0.1016/j.seppur.2.

[13]. Holland, H., \& Albrecht, C. (2013). The worldwide academic field of business ethics: Scholars' perceptions of the most important issues. Journal of Business Ethics, 117(4), 777-788. doi: 10.1007/s10551-013-1718-y.

[14]. Kemenristekdikti. (2019). Kemenristekdikti dorong kampus jadi pencetak pengusaha baru. Retrieved from https://www.jpnn.com/. https://www.jpnn.com/news/kemenri stekdikti-dorong-kampus-jadipencetak-pengusaha-baru?page $=2$.

[15]. Keraf, A. S. (2002). Etika lingkungan. Jakarta: Penerbit Buku Kompas.

[16]. Kristanto, N. H., Lestari, N., \& Subekti, S. (2014). Etika profesi kearsipan. Jakarta: Universitas Terbuka.

[17]. Loren, B. (2000). Kamus filsafat. Jakarta: PT Gramedia Pustaka.

[18]. Marques, J. (2019). Creativity and morality in business education: Toward a trans-disciplinary approach. The International of Management Education, 17(1), 1525. doi: 10.1016/j.ijme.2018.11.001.

[19]. Meleong, L. J. (2012). Metode penelitian kualitatif. Bandung: Remaja Rosdakarya.

[20]. Miles, M. B., \& Huberman, A. M. (1992). Qualitative data analysis: A methods sourcebook [T. R. Rohidi, Trans]. Jakarta: UI-Press.

[21]. Muslim, M. (2019). Problema etika dalam era baru manajemen. Jurnal Manajemen Bisnis, 22(2), 205-214.

[22]. Nizar (2018). Hubungan etika dan agama dalam kehidupan sosial. Jurnal Arajang, 1(1), 27-35. doi: 10.31605/arajang.v1i1.44.

[23]. Pararuk, H. S. R., \& Gamaliel, H. (2018). Analisis persepsi terkait prinsip-prinsip etika profesi akuntan (Studi pada mahasiswa akuntansi fakultas ekonomi dan bisnis Universitas Sam Ratulangi Manado). Jurnal EMBA, 6(4), 4093-4102.

[24]. Royaee, R., Ahmadi, S. A., \& Jari, A. (2013). Students' and faculty members' perceptions of the importance of business ethics and accounting ethics education: Iranian case. Asian Journal of Bussiness Ethics, 2(2),163-171. doi: 10.1007/s13520-012-0023-7.

[25]. Robbins, S. (2001). Perilaku organisasi- konsep kontroversiaplikasi[edisi 8]. Jakarta: PT 
Prenhallindo.

[26]. Salama, N. (January, 2020). Sisi gelap suap korporasi. Retrieved from https://news.detik.com/kolom/d4867647/sisi-gelap-suap-korporasi.

[27]. Satrya, I. G. B. H., \& Suwandana, I. G. M. (2015). Potensi kewirausahaan mahasiswa di fakultas ekonomi dan bisnis Universitas Udayana. E-Jurnal Manajemen Universitas Udayana, 4(12).

[28]. Sigurjonsson, T. O., Arnardottir, A. A., Vaiman, V., \& Rikhardsson, P. (2015). Managers' views on ethics education in business schools: An empirical study. Journal of Business Ethic, 130(1), 1-13. doi: 10.1007/s10551-014-2202-z.
[29]. Siagian, S. P. (1996). Etika bisnis. Jakarta: PT Pustaka Binaan Pressindo.

[30]. Stăiculescu, C., Richiţeanu-Năstase, E. R., \& Dobrea, R. C. (2015). The university and the business environment - partnership for education. Procedia - Social Behavioral Science, 180, 211-218. doi: 10.1016/j.sbspro.2015.02.107.

[31]. Suseno, F. M. (1996). Etika sosial. Jakarta: Gramedia Pustaka.

[32]. Wirawan, I. B. (2012). Teori-teori sosial dalam tiga paradigma: Fakta sosial, definisi sosial dan perilaku sosial. Jakarta: Prenadamedia Group. 